\title{
Analysis of the Effect of Earnings Management on Audit Service Fees in Five ASEAN-5 Countries
}

\author{
Berliana Anggun Dewinta ${ }^{1 \bowtie}$ and Aria Farah Mita ${ }^{2}$ \\ Department of Accounting, Faculty of Economics \& Business, Universitas Indonesia \\ Jl Awi No.88, Kukusan, Kecamatan Beji, Depok, West Java16425 \\ DOI: http://dx.doi.org/10.15294/jda.v12i2.25252
}

Submitted: January $8^{\text {th }} 2020$ Revised: August $31^{\text {th }} 2020$ Accepted: September $1^{\text {st }} 2020$ Published: September $26^{\text {th }} 2020$

\begin{abstract}
This research aims to provide empirical evidence about the effect of earnings management on the audit fee spent by listed firms in ASEAN-5. This research was conducted using regression analysis with sample of 5.396 firm year listed in ASEAN countries, such as Indonesia, Malaysia, Philippines, Singapore, and Thailand from 2010-2014. The result of this study indicates that earnings management will increase audit fee. It is due to earnings management increase inherent risk faced by auditor.
\end{abstract}

Keywords: earnings management; discretionary accruals; audit fee; south-east asia region

\section{How to cite (APA 6th Style)}

Dewinta, B., \& Mita, A. (2020). Analysis of the Effect of Earnings Management on Audit Service Fees in Five ASEAN-5 Countries. Jurnal Dinamika Akuntansi, 12(2). 114-126, doi:https://doi. org/10.15294/jda.v12i2.25252

\section{INTRODUCTION}

Financial statements are one of the media used by companies to communicate with users of financial statements. Financial statements are used by external parties to view the condition of company in the past and at present as well as predict the performance of company in the future and the financial position of company with the aim of investment, credit, and other economic decisions. Financial statements are also used in assessments for creditors, lenders, and investors.

According to the Basic Framework for the Presentation and Disclosure of Financial Statements (IAI, 2017), qualitative characteristics in financial statements that are useful in decision making, must be understandable, relevant, reliable, and comparable. The fulfilment of these qualitative characteristics can be limited by costs or benefits so that in practice these qualitative characteristics can be sacrificed to be a counterweight. The Basic Framework for the Presentation and Disclosure of Financial Statements states that with these qualitative characteristics the financial statements should be presented fairly.

Transparent information makes the company more attractive for investors. This can improve coordination between companies and investors regarding capital investment decisions and build trust that can increase firm value. If the company does not disclose the information, the firm value in the eyes of investors will decrease (Bazrafshan et al., 2014).

Financial statements are used to provide information to stakeholders regarding company

author $(\bowtie)$

E-mail: farah_mj@yahoo.com 
performance. Financial statements are a way to reduce asymmetric information. Reliable information is an important issue for companies because all companies experience asymmetric information between insiders and outsiders investors (Flannery et al., 2004). Asymmetric information that occurs between stakeholders and managers is an old case of agency theory (the principal-agent problem). If both parties in the agency relationship are assumed to be trying to maximize their personal interests and if supervision on the manager's performance is not free, then these are the reasons for the emergence of agents (managers) who do not always act in the interests of the principals (Wallace, 2004). Asymmetric information arises because stakeholders do not have a direct understanding regarding corporate performance, in contrast to the managers who own it.

If financial statement is a manager's way of conveying company performance, then there must be standards that limit the use of managers' consideration in financial statements. Managers can use their knowledge of business and opportunities to select reporting methods, estimates, and disclosures appropriate to the company's economic business, potentially increasing the accounting value used as a form of communication.

Managers have their own motive in manipulating reported earnings. Managers attempt to give signals about the company's prospects in the future to outsiders or managers use accounting items that are indeed intended to do their discretion opportunistically or efficiently (Aljifri, 2007). In the literature, there are two types of earnings management, (Omid et al., 2012), namely earnings management that is efficient and opportunistic. Earnings management is efficient if managers use their discretion to give confidential company information about profitability, which has not been seen in historical cost-based earnings. Earnings management is opportunistic if managers use their discretion to maximize their profits.

Audit process is an imperfect process because auditors do not examine the overall financial statements. In addition, consideration made by management also creates earnings management opportunities, in which managers can choose reporting and estimation methods that do not accurately reflect corporate economy. Audit process is a way to assess the quality of financial statements because it is expected that with financial statements that have been audited, the financial statements presented to external parties can be reliable.

According to Securities Exchange Commission in the United States (SEC), low balling is price competition between competitors; can lead to overproduction of dishonesty in reporting, which can reduce auditor independence (DeAngelo, 1981). Auditor's encouragement to prevent bias in financial statements differs systematically depending on whether the client pays more or less than normal audit fees (Choi et al., 2010).

When determining audit service fees, there is a positive relationship between audit expenses and estimates that the company will experience losses in the future, which stem from the auditor's involvement in current financial statements. Although these two things are difficult to observe, the cost of audit services is closely related to the proxies of cost drivers: client size, client risk and client complexity (Hay et al., 2006). Total audit service fee paid to auditor is a sensible way of measuring auditor's independence to the client (Chung \& Kallapur, 2003; DeAngelo, 1981; Reynolds \& Francis, 2000)

The relationship between earnings management and audit service fees has been the topic of several studies (Abbott et al., 2006; Alali, 2011; Ghanbari et al., 2014; Gul et al., 2003; Larcker \& Richardson, 2004). The relationship between earnings management and audit service fees is an interesting topic to be examined because there is still debate about the accounting profession and the appropriateness of providing audit and non-audit services. Auditor independence is considered very important for the integrity and reliability of financial statements (Wallman, 1996). Bedard \& Johnstone (2004) found that auditor's response to the risk of earnings management is the increase of ex ante in the number of auditor working hours that are planned and the invoices given to clients. Bargaining theories (Antle \& Nalebuff, 1991) stated there is an indirect relationship between the fees received by the auditors and the characteristics of the financial statements, such 
as abnormal accruals.

Gul et al., (2003) indicated that accruals are used opportunistically by managers to hide performance and / or to delay a high portion of current earnings from being recognized in the future. Accounting estimation has a high inherent risk and discretionary accruals are associated with this estimation, so that the auditor is expected to gather more evidence, employs large numbers of staff, and checks each completed job carefully when the inherent risk is high. Therefore, the greater the audit risk, the more time is allocated, thus increasing the cost of audit services.

This study aims to provide empirical evidence regarding the relationship between earnings management and audit service fees where there is still little literature that discusses the relationship between the two. This study is different from the previous studies since this study uses the setting of an ASEAN region are, while the previous studies only focus on one country. The research design regarding audit fee with the ASEAN regional setting is an interesting thing. The ASEAN regional area consists of countries that are mostly included in developing countries. As developing countries, many investors make ASEAN countries as a place to invest because of their low costs and easy access. Therefore, this is used by company managements to make their financial statements as attractive as possible, one of which is by managing earnings through discretionary accruals. Conversely, investors want informative financial statements.

This study consists of five parts. The first part is discussion. The second part is literature review and hypothesis development. The third part discusses research methods, including data collection techniques as well as research models and variable measurements. The fourth part discusses the research results and the fifth part is conclusion.

Stewardship theory is defined as a situation where managers do not have personal interests but are more concerned with the wishes of the principal. Stewards will act in a pro-manner, that is, actions that prioritize the interests of the owner and the organization as common interests. This behaviour arises because of the good relationship between the owner and the steward as well as the ideal environment and organization. Managers, as stewards, will maximize the company's performance and this will be achieved when managers position themselves as stewards who are required to act in the interests of the owner (Madison, 2014).

There are times when the interests of the steward and the principal are not the same. When this happens, the steward will try to cooperate with the principal rather than oppose it because the organizational goals are the steward's primary goals. The steward will protect and maximize the wealth of the organization with the company's performance so that the maximum utility is obtained. An important assumption of stewardship theory is that the manager adjusts his objectives to the objectives of the principal. Although stewards still prioritize organization, that does not mean stewards do not have their own desires (Raharjo, 2007).

Agency theory was first introduced by Jensen and Meckling in 1976. Jensen and Meckling describe an agency relationship with a contract between principal (owner) and another party (agent) to use company resources for the benefit of the owner. This contract signifies that the owner gives the agent authority to make decisions so that the agent can transfer the owner's property to him if the agent does not.

In the situation above, both the owner and the agent will maximize their satisfaction and it is difficult to believe that the agent (in the case of manager) will always act for the benefit of the owner. Agency problems that arise are problems that encourage agents to act as if to maximize owner's wealth (Godfrey et al., 2010).

This agency problem eventually raises agency cost, which is an additional cost incurred by the owner, which has an impact on decreasing the owner's wealth with the aim of ensuring that the agent will act in the owner's interests. Jensen and Meckling categorize agency costs into three, namely monitoring costs, bonding costs and residual loss.

Monitoring cost is the cost incurred by the owner to supervise the agent's actions. These expenses are used by the owner to measure, observe, and control agent behaviour. Examples of monitoring costs are audit fees, costs of forming employee compensation plans, budget 
restrictions, and operational regulations. These fees are incurred by the owner to guarantee that the agent, in this case the manager, will act for the benefit of the owner and ensure that the agent will compensate if the agent does not act in the owner's interest. The amount of costs incurred by the owner based on the estimation of supervision level which is called price protection. This also applies in debt contracts, where the manager in this case acts for the interests of shareholders, is an agent for lenders.

Bonding cost is the costs incurred to build and fulfil the mechanism created by the agent, where the agent guarantees that the agent will act in the interests of the owner, or to guarantee that they will make compensation if their actions are against the interests of the owner.

The agent's interest will still not be in accordance with what the principal wants even though the bonding cost and monitoring cost have been issued. This mismatch results in residual loss, which is the net value of the output produced by the agent but in reality is lower than what the principal expected.

Earnings management can be defined as a manager's choice through accounting policies or concrete actions, which affect earnings for a specific purpose. Managers can choose one of the accounting policies from a series of existing policies (for example, GAAP) and it is natural that managers will choose accounting policies that are profitable to them. The real action a manager can take is to cut R\&D costs. This selection is motivated by market efficiency and contract, or opportunism and resistance to market efficiency (Scott, 2012, p. 423). According to Healy \& Wahlen (1999), earnings management occurs when managers make consideration (discretions) when preparing financial reports and recording transactions, which result in changes in financial statements. This behaviour then has an impact on actions that mislead stakeholders, either to provide information about corporate performance or for other purposes, such as contracts that depend on the numbers being reported on. Earnings management occurs through changes in the accrual or deviation process from normal business activities or both continuously.

Earning management patterns (Scott, 2012, p. 425) are carried out in the form of minimizing profits, maximizing profits, or smoothing profits. Earnings management is carried out by managers with several motivations (Scott 2012, p. 426), namely (1). The objective of maximizing the bonus received from the company, (2) Keeping management to be able to meet the requirements in the loan agreement contract; (3) Maintaining reputation and meeting investor expectations; (4) Other objectives, for example when want to do an IPO (Initial Public Offering) so that the company looks good.

The most common approach to examine earnings management is total or aggregate accrual approach. This can be achieved by dividing total accruals into two parts, namely (1) nondiscretionary or the normal level of accruals required in corporate operations; (2) estimation or discretionary or unexpected accruals that become proxy for company manipulation behaviour. Non-discretionary accruals are accruals that normally cannot be influenced by managers, in other words discretionary is the part that can be influenced and managed by managers.

The determination of audit service fees is still a question, whether it has been in accordance with the applicable regulations or there are certain conditions so that there is a bargain between client and auditor. The determination of audit service fees that are too high or too low can affect the audit quality resulted. According to (Simunic, 1980), audit service fee is a product of the unit price and quantity of audit services, while the difference between audit service fees shows the impact of differences in quantity or price provided. The factors that determine audit service fees are clients' firm size, the complexity of client's business company, audit risk and auditor office size.

Malaysian Institute of Accountants (MIA) ${ }^{1}$ divides two ways in determining audit service fees, namely time basis and value basis. Time basis was often used, but this basis has weaknesses, namely mistake in time recording on the time sheet and provision of non-assurance services provided when providing assurance services. The time recording mistake could result in lower audit service fees. Based on the value basis, the appropriate calculation of audit service fees is by

1 (http://www.mia.org.my/handbook/guide/RPG/RPG7.pdf) 
using value consideration. Advice given by auditors and benefits, whether tangible or not, what is accepted by the client must be considered. The auditor must clearly inform the value-drivers of his services, namely, what items are considered when determining the cost of audit services.

Discretionary accruals are an important instrument used by companies in manipulating earnings presented in financial statements. The level of discretionary accruals will be a significant factor in determining audit risk associated with a particular client. Furthermore, the higher the risk associated with a particular company, the more time and effort the auditor provides to audit the company's financial statements so that it is almost certain that the cost of audit services will increase.

This statement is in accordance with Schelleman \& Knechel's study (2010) which indicates that auditor will increase his effort in conducting audits in the presence of short-term accruals which are higher than the estimation as an indication of earnings management. Alali (2011; Gul et al., (2003) made a hypothesis that the impact of discretionary accruals is an inherent risk to the client company being audited so that there is a positive relationship between audit service fees and discretionary accruals recorded by the company. The higher the audit service fees, the greater the acceptance of abnormal accruals made by the client (Antle et al., 2006).

Hackenbrack et al. (2012) conducted interviews with five audit partners from three Big 4 KAPs in the United States. The results show that the majority of audit service fees are contracts with a fixed fee value where the audit service fee for additional services must be approved by client's audit committee, either pre-approved or negotiated on an unusual transaction basis or events that require additional audit time and effort. This indicates that audit service fee or contract with a fixed audit fee value is negotiated by the auditor based on the auditor's expectations on the amount of earnings management practice. The cost of audit services depends more on the ex ante audit firm expectations to the client's earnings management practices than on the actual level of earnings management performed by the client.

The results of research conducted by Bedard \& Johnstone (2004) shows that auditor's plan to increase the business and billing rates for clients who have a risk of earnings manipulation has a significant positive relationship and is strengthened by the presence of corporate governance risk. The assessment on earnings management risk carried out by audit firm before the audit engagement is significantly related to the amount of audit service fees charged by the audit firm. Based on the research results of Bedard \& Johnstone (2004), it is assumed that annually auditors will make a review of the factors, both general and specific, that affect the audit responsibilities for a particular audit client. Then, the auditors will determine the appropriate amount of audit service fee, according to their considerations. Likewise, audit clients do, where senior management, namely the audit committee, also determines the amount of the audit service fee for the following year.

The negotiation process between the audit client and the audit firm will reach an agreement on the amount of audit service fee for the following year. The aspects considered in negotiations will be based on the way the auditors resolve accounting and auditing issues that arose during the audit in the previous year and the desire of the audit firm and the desire of the audit client to state how the audit should be carried out and how to resolve accounting and auditing issues in the following year. The amount of approved audit fees for the following year reflects the information regarding the level of earnings management in the previous year. Based on this, the hypothesis developed is:

\section{$H_{1}$ : The level of earnings management has a positive effect on the cost of audit services}

\section{METHODS}

This study used a sample of companies listed on the stock exchanges of each country, namely Indonesia, Malaysia, Philippines, Singapore, and Thailand in the period 2010-2014. The sample selection used purposive sampling method with the criteria listed in Table 1 below. 
Table 1. Sample Selection Technique

\begin{tabular}{lcllll}
\hline \multicolumn{1}{c}{ Criteria } & 2010 & 2011 & 2012 & \multicolumn{1}{c}{2013} & 2014 \\
\hline Exchange-listed company & 2598 & 2688 & 2756 & 2875 & 3011 \\
Companies included in the financial industry & $(531)$ & $(545)$ & $(562)$ & $(593)$ & $(626)$ \\
Companies that did not disclose audit service fees & $(734)$ & $(616)$ & $(1001)$ & $(1201)$ & $(1271)$ \\
Companies with incomplete financial data & $(180)$ & $(211)$ & $(175)$ & $(137)$ & $(149)$ \\
Number of companies that become sample & 1153 & 1316 & 1018 & 944 & 965 \\
\hline Total observatio & 5396 & & & & \\
\hline
\end{tabular}

The model used in this study refers to Nam (2014) with modifications.

$$
\begin{aligned}
& \mathrm{LNAF}_{\mathrm{it}}=\alpha_{0}+\alpha_{1} \mathrm{ABS}_{-} \mathrm{DACC} \mathrm{t}_{\mathrm{t}-1}+\alpha_{2} \mathrm{LNTA}_{\mathrm{it}}+\alpha_{3} \mathrm{INVREC}_{\mathrm{it}}+\alpha_{4} \mathrm{LOSS}_{\mathrm{it}}+\alpha_{5} \mathrm{ROA}_{\mathrm{it}}+\alpha_{6} \mathrm{BTM}_{\mathrm{it}}+\alpha_{7} \mathrm{C}_{-} \\
& \mathrm{REV}_{\mathrm{it}}+\alpha_{8} \mathrm{LEVE}_{\mathrm{it}}+\alpha_{9} \mathrm{LIQUID}_{\mathrm{it}}+\alpha_{10} \text { BIG4 }_{\mathrm{it}}+\alpha_{11} \mathrm{C}_{-} \text {AUDITOR }_{\mathrm{it}}+\alpha_{12} \mathrm{LNGDP}_{\mathrm{it}}+\varepsilon_{\mathrm{it}}
\end{aligned}
$$

The dependent variable was (LNAF) audit service fees. The independent variable that became the focus of the research was (ABS_DACC) the level of corporate earning management. The hypothesis is said to be accepted if $\boldsymbol{\alpha}_{1}$ is significant positive. The control variables used in this study were variables that also influence audit service fees. The LNTA variable was included to control the effect of firm size on audit service fees. The variables of NVREC, LOSS, ROA, BTM, C_REV, LEVE, LIQUID were included in the research model to control for the differences of complexity, audit risk and firm profitability that have an effect on audit service fees. The variable of BIG4 was included to control the effect of the auditor size and brand (name of leading auditor). The variable of C_AUDITOR was included to control the effect of auditor switching on audit service fees. The LNGDP variable was included as a control over differences in the costs of auditing services between countries.

\begin{tabular}{|c|c|c|}
\hline Variables & Information & Data Sources \\
\hline LNAF & $\begin{array}{l}\text { Natural logarithm of the total actual audit service fees } \\
\text { paid by the company }\end{array}$ & $\begin{array}{l}\text { Thomson Reuters (Eikon } \\
\text { and Datastream) }\end{array}$ \\
\hline $\mathrm{ABS}_{-} \mathrm{DACC}_{\mathrm{it}-1}$ & $\begin{array}{l}\text { The absolute value of discretionary accruals in the year } \\
(\mathrm{t}-1)\end{array}$ & $\begin{array}{l}\text { Based on the Kothari model } \\
\text { calculations (2005) }\end{array}$ \\
\hline LNTA $_{\text {it }}$ & Natural logarithm of total assets & Thomson Reuters (Eikon) \\
\hline INVREC $_{\text {it }}$ & $\begin{array}{l}\text { The ratio of total inventory and accounts receivable di- } \\
\text { vided by total assets }\end{array}$ & Thomson Reuters (Eikon) \\
\hline LOSS $_{\text {it }}$ & $\begin{array}{l}\text { Dummy variable, given value } 1 \text { if the company experi- } \\
\text { ences a loss in that year and given value } 0 \text { if the opposite }\end{array}$ & Thomson Reuters (Eikon) \\
\hline $\mathrm{ROA}_{\mathrm{it}}$ & $\begin{array}{l}\text { Net income before extraordinary items divided by total } \\
\text { assets }\end{array}$ & Thomson Reuters (Eikon) \\
\hline $\mathrm{BTM}_{\mathrm{it}}$ & Book value divided by market value for equity & Thomson Reuters (Eikon) \\
\hline C_REV ${ }_{\text {it }}$ & $\begin{array}{l}\text { Change in revenue divided by total assets for the previ- } \\
\text { ous year }\end{array}$ & Thomson Reuters (Eikon) \\
\hline $\mathrm{LEVE}_{\text {it }}$ & Ratio of total liabilities divided by total assets & Thomson Reuters (Eikon) \\
\hline LIQUID $_{\text {it }}$ & $\begin{array}{l}\text { The ratio of total current assets divided by total current } \\
\text { liabilities }\end{array}$ & Thomson Reuters (Eikon) \\
\hline $\mathrm{BIG} 4_{\text {it }}$ & $\begin{array}{l}\text { Dummy, given value } 1 \text { if the company is audited by big } \\
4 \mathrm{KAP} \text { and given value } 0 \text { otherwise }\end{array}$ & Thomson Reuters (Eikon) \\
\hline C_AUDITOR ${ }_{\text {it }}$ & $\begin{array}{l}\text { Dummy, given value } 1 \text { if the company changes auditors } \\
\text { and given value } 0 \text { if otherwise }\end{array}$ & Thomson Reuters (Eikon) \\
\hline LNGDP & $\begin{array}{l}\text { Natural logarithm of total Gross Domestic Product per } \\
\text { Capita at the end of the year for each country }\end{array}$ & $\begin{array}{l}\text { GDP per Capita Worldbank } \\
\text { (http://data.worldbank.org) }\end{array}$ \\
\hline$\varepsilon_{\mathrm{it}}$ & Residual error & \\
\hline
\end{tabular}

Table 2. Descriptions of Variable and Data Sources 
This study estimates discretionary accruals (DACC) using Kothari's study model (2005). The total accruals are calculated as follows:

$$
\mathrm{TA}_{\mathrm{it}}=\mathrm{NI}-\mathrm{CFO}
$$

where:

$\begin{array}{ll}\text { TA } & =\text { Corporate total accruals in period } t \\ \text { NI } & =\text { Company net profit } / \text { loss; } \\ \text { CFO } & =\text { Cash flows from operating activities. }\end{array}$

Kothari et al. (2005) made a matched performance model on earnings and discretionary accruals quality by including corporate return on assets (ROA) and the constant in modified Jones (1995) with the following regression model:

$$
\begin{aligned}
\left(\frac{\mathbf{T A C}_{\mathrm{i}, \mathrm{t}}}{\mathbf{T A}_{\mathrm{i},}}\right)= & \propto_{0}+\propto_{1}\left(\frac{1}{\mathbf{T A}_{\mathrm{i}, \mathrm{t}-1}}\right)+\propto_{2}\left(\frac{\Delta \mathbf{R E V}_{i t}-\Delta \mathbf{R E C}_{\mathrm{it}}}{\mathbf{T A}_{\mathrm{i}, \mathrm{t}-1}}\right)+\propto_{3} \mathbf{P P E}_{\mathrm{i}, \mathrm{t}}+\propto_{4} \mathbf{R O A}_{\mathrm{i}, \mathrm{t}-1} \\
& +\varepsilon_{\mathrm{i}, \mathrm{t}}
\end{aligned}
$$

where:

$\mathrm{TAC}_{\mathrm{i}, \mathrm{t}}=$ Corporate total accruals in period $\mathrm{t}$;

$\mathrm{TA}^{\mathrm{i}, \mathrm{t}}=$ Total assets at the end of the year $\mathrm{t}$;

$\mathrm{TA}_{\mathrm{it.1}}^{\mathrm{it}}=$ Total assets at the end of year $\mathrm{t}-1$;

$\Delta \mathrm{REV}_{\mathrm{i}, \mathrm{t}}=$ Change in net sales from year $(\mathrm{t}-1)$ to year $\mathrm{t}$;

$\Delta \mathrm{REC}_{\mathrm{i}, \mathrm{t}}^{\mathrm{i}}=$ Change in total net receivables from year $(\mathrm{t}-1)$ to year $\mathrm{t}$;

$\mathrm{PPE}_{\mathrm{i,t}} \quad=$ Total gross property, plan, and equipment year t;

$\mathrm{ROA}_{\mathrm{i}, \mathrm{t}-1}=$ Rate of return on assets in year $\mathrm{t}-1$

\section{RESULTS AND DISCUSSIONS}

Descriptive statistics on the variables used in the study are presented in Table 3. The

\begin{tabular}{|c|c|c|c|c|c|c|}
\hline & $\begin{array}{l}\text { Obser- } \\
\text { vation }\end{array}$ & Mean & Median & Std Dev & Minimum & Maximum \\
\hline$\overline{\mathrm{AF} \text { (USD) }}$ & 5,396 & 25.0617 & 72.970 & 784.353 & 962 & $7,608,818$ \\
\hline ABS_DACC & 5,396 & 0.12260880 & 0.09919370 & 0.10387397 & 0.00000143 & 0.54063431 \\
\hline TA (USD) & 5,396 & $681,000,000$ & $106,646,287$ & $1,960,000,000$ & 503,000 & $12,420,691,818$ \\
\hline INVREC & 5,396 & 0.32795892 & 0.31553789 & 0.19709243 & 0.00001572 & 0.91977426 \\
\hline LOSS & 5,396 & $20.98 \%$ & - & - & 0 & 1 \\
\hline ROA & 5,396 & 0.03891992 & 0.04278461 & 0.03891990 & 306371 & 0.57729503 \\
\hline BTM & 5,396 & 1.26909449 & 1.04673292 & 1.11098479 & -4.19604627 & 6.74096326 \\
\hline C_REV & 5,396 & 0.08204833 & 0.35433446 & 0.03657773 & -2.67902087 & 2.88995268 \\
\hline LEVE & 5,396 & 0.42809333 & 0.41768900 & 0.22479673 & 244357 & 1.36533934 \\
\hline LIQUID & 5,396 & 2.82754894 & 1.78292468 & 3.41935836 & 0.01241669 & 25.32445570 \\
\hline $\mathrm{BIG} 4$ & 5,396 & $52.09 \%$ & - & - & 0 & 1 \\
\hline C_AUDITOR & 5,396 & $16.01 \%$ & - & - & 0 & \\
\hline GDP (USD) & 5,396 & 23,132 & 10974 & 20,942 & 2,145 & 56,285 \\
\hline
\end{tabular}
following results are presented after winsorizing.

Table 3. Descriptive Statistics

AF : total audit fees paid by the company (in USD); ABS_DACC : $_{\text {:- }}$ absolute value of discretionary accruals calculated by modified Jones with ROA (Kothari, 2005); TA: total asset (in USD); INVREC: is the amount of inventory and receivable divided by total assets; LOSS: is dummy variable, which is given value 1 if the company reports a loss in year $\mathrm{t}$ and 0 otherwise; BTM: book to market ratio which is calculated by dividing book value by the market value of the company; C_REV: change in revenue value from year t-1 to year $\mathrm{t}$ and divided by total assets in year t; LEVE: leverage ratio is calculated by dividing total liabilities by total assets; LIQUID: liquidity ratio is calculated by dividing total current liabilities by total current assets; BIG4: dummy variable, given value 1 if the company is audited by BIG 4 KAP and 0 otherwise; C_AUDITOR: dummy variable, given value 1 if the company changes the external auditor and 0 if otherwise; GDP: Gross Domestic Product per capita of the country in year $t$ (in USD) . 
Based on the table above, it can be concluded that the audit fee variable has scattered and varied data because the standard deviation value is greater than the mean value. As many as $17 \%$ of the sample pay audit fees above the average value and $73 \%$ that pay audit fees above the average value are audited by Big 4 KAP. The difference in the amount of audit service fees paid by the company is based on the characteristics of the company so that it cannot be compared even though the company is in the same industry or has the same firm size. Other factors that are considered by the auditor are the risks faced by the auditors and the types of auditor.

The average value of discretionary accruals is 0.122 which indicates that the sample companies have an accrual earnings management level by $12.26 \%$ of total assets. Total assets are used to know firm size. Based on the years of the companies being sampled, it can be concluded that only $3 \%$ have total assets above the average value. This indicates that most companies are in the medium company range when comparing the minimum and maximum values from the data.

The INVREC variable has an average value which indicates that the percentage of the total inventory and receivables to total assets for the sample firm year is $32.79 \%$. The maximum value of $91.97 \%$ indicates that these two components are the main components of the company's assets.

The minimum value of the ROA variable which has negative value is caused due to the company reporting the net loss in the year t. The ROA variable describes the company's ability to generate income with its own assets so that the higher the ROA, the more effective a company is. The ROA variable in this study has varied and scattered characteristics since the standard deviation value is higher than the average value. The mean value of 0.0389 indicates that $\$ 1$ of the company's assets will generate $\$ 3.89$ in net income before the extraordinary event. This value shows if some of the companies have a positive level of profitability.

The minimum value of the BTM variable which has negative value is caused by several companies reporting negative book value. This ratio is used to control the estimated growth in the company's operations and if the BTM ratio is above the estimation, then this growth is considered as discretionary accruals. The maximum value of the BTM ratio indicates that the company has a book value of $6 x$ greater than its market value.

The C_REV variable has a negative minimum value since there are companies that experience a decrease in revenue in the year t. C_REV can be used to assess the company's growth as seen from the increase or decrease in revenue compared to the total assets of the previous year. The average company shows a growth of $8.2 \%$, where there is a company that experience revenue growth of $289 \%$ compared to the total assets reported in the previous year.

The LEVE and LIQUID variables describe the company's ability to pay short-term and long-term obligations. The greater the value of these ratio, the better the company's ability to pay off its obligations. On average, firm year which becomes sample can pay off long-term liabilities with total assets owned by 0.42 . This means that for every $\$ 1$ of total liabilities can be covered by 0.42 of total assets so that if the company's long-term liabilities are due, this can only be paid with less than half of the total assets. However, this is inversely proportional to LIQUID, where on average the companies can pay off short-term obligations by 2.82 . This means that every $\$ 1$ of current liability can be paid off by $\$ 2.82$ of current assets. However, there are companies that have a poor level of solvency with a ratio value of 0.0012 .

The GDP variable is one of the methods used to calculate national income. In this study, the data used is GDP per capita, which is the average income of the population in a country, which is obtained from dividing the national income of a country with the population of that country. Based on the data, Singapore in 2014 has the highest GDP value and Philippines in 2010 has the lowest GDP value.

The results of descriptive statistics show that $21 \%$ of the firm year report losses in the current year while the rest report net income. Most of the firm years that become sample are audited by the BIG4 accounting office, $52 \%$ and the rest by non-BIG4. This study does not separate if there is BIG4 conducts cross-country audits, such as SGV, which is an affiliate of Ernst and Young in Philippines, which conducts audits in Singapore. Only 16\% of the companies experience auditor 
switching in year t. The C_AUDITOR variable in this study aims to see whether there is a low balling effect.

Statistical testing uses the panel method. After conducting the model selection testing, the model used in this study is fixed effect model. The results of hypothesis testing can be seen in Table 4. The hypothesis in this study explains that the effect of earnings management in the previous year on audit service fee this year is positive..

Table 4. Hypothesis Testing Results

\begin{tabular}{|c|c|c|c|c|}
\hline Variables & Prediction & Coefficient & Probability & Significance \\
\hline $\mathrm{ABS}_{-} \mathrm{DACC}_{\mathrm{t}-1}$ & + & 0.255 & 0.02 & ** \\
\hline LNTA & + & 0.485 & 0.00 & $* * *$ \\
\hline INVREC & + & 0.231 & 0.00 & $* * *$ \\
\hline LOSS & + & 0.099 & 0.00 & $* * *$ \\
\hline ROA & $?$ & -0.413 & 0.00 & $* * *$ \\
\hline BTM & $?$ & -0.026 & 0.00 & $* * *$ \\
\hline C_REV & + & 0.012 & 0.37 & \\
\hline LEVE & $?$ & 0.161 & 0.01 & ** \\
\hline LIQUID & $?$ & -0.020 & 0.00 & $* * *$ \\
\hline BIG4 & + & 0.150 & 0.00 & $* * *$ \\
\hline C_AUDITOR & - & 0.014 & 0.34 & \\
\hline LNGDP & + & 0.491 & 0.00 & $* * *$ \\
\hline Observations & \multicolumn{4}{|c|}{5.396} \\
\hline Adj $R^{2}$ & \multicolumn{4}{|c|}{0.624} \\
\hline F-Statistics & \multicolumn{4}{|c|}{0.000} \\
\hline
\end{tabular}

LNAF : natural logarithm of the total audit fee paid by the company; ABS_DACCt-1: absolute value of discretionary accruals calculated by modified Jones with ROA (Kothari, 2005); LNTA: natural logarithm of total assets; INVREC: total inventory and receivable divided by total assets; LOSS: dummy variable, which is given valuel if the company reports a loss in year $t$ and 0 if the opposite; BTM: book to market ratio calculated by dividing book value by company market value; $C \_R E V$ : change in revenue value from year $t-1$ to year $t$ and divided by total assets in year t; LEVE: leverage ratio is calculated by dividing total liabilities by total assets; LIQUID: liquidity ratio is calculated by dividing total current liabilities by total current assets; BIG4: dummy variable, given value 1 if the company is audited by BIG 4 KAP and 0 otherwise; C_AUDITOR: dummy variable, given value of 1 if the company changes the external auditor and 0 if otherwise; LNGDP: Natural logarithm of Gross Domestic Product per capita. ${ }^{* * *}$, ${ }^{* *}$, are $1 \%, 5 \%$, and $10 \%$ significance.

The results of the t-statistic test show that the C_REV and C_AUDITOR variables do not have significant effect on the LNAF variable. The ABS_DACC t- $_{-1}$ ariable as the independent variable has a positive and significant effect on audit service fees, according to the hypothesis. This is due to the auditors will conduct reviews each year regarding general and specific factors that impact on the responsibilities for each client. The auditors will also assess the risk of earning management at the time of the initial audit engagement which determines the amount of audit service fees, where for companies that have a high risk of earnings management, the audit service fees charged by the auditor will increase. For the companies that do not change auditors, the auditor's experience when completing the audit in the previous year becomes a considered factor so that there is a possibility of an increase in the audit service fees. The increase in the audit service fees is used by the auditor to increase the number of staff hired and the longer time to complete the audit as a result of the risk of earnings management that has not been recognized by the auditor at the start of the audit engagement. The increase in the audit service fees is used as 
compensation so that the auditor is assured that the financial statements are fair without material misstatement.

Firm size is a factor that is considered in determining the amount of audit service fees since the larger the company, the more time the auditor needs to complete the audit. Audit complexity, with the proxy of total inventory and receivables divided by total assets, has a significant effect on the audit service fees, according to initial prediction. This is due to the greater the value of the inventory and receivables presented, the higher the risk faced by the auditors since inventory and receivables are risky components in the financial statements. In addition, the auditor must perform certain tests to obtain assurance that the inventory value presented is still in good condition and is suitable for sale. The value of receivables presented by the company must be presented at the amount that may be collectible and if there are receivables related to the related party, the clause for settlement or write-off accounts receivable must be clear. These factors then take longer time for the auditors to complete their duties.

Audit risk uses proxies for loss reported by the company, return on assets, book to market ratio, changes in revenue, short-term and long-term debt. Variables of ROA, BTM, C_REV, LEVE, and LIQUID. The LOSS variable has a positive and significant effect on audit service fees. Companies that present net loss have a greater risk because the auditors must have sufficient confidence about the business continuity. The auditor must disclose strong reasons if the company can continue the business or if the losses suffered by the company are only temporary. Initially, ROA was estimated to have an effect on the audit service fees, but the result shows that ROA has a significant negative relationship to the audit service fees. Companies with large ROA values have good performance so that the relationship between ROA and audit service fees is inversely related.

The BTM variable is a variable that is predicted to have an effect on the audit service fees due to the higher the BTM ratio, the greater the risk of litigation. However, the regression result shows that BTM has a significant negative effect on the audit service fees. The C_REV variable is one of the variables that has an insignificant relationship. Changes in revenue affect the determination of audit service fees. An increase in revenue is not a major consideration for auditors when determining the cost of audit services since most companies experience an increase in revenue every year. An increase in revenue is a factor to consider if there is a significant increase. The LEVE variable shows a significant positive result. The result is consistent with study of Pratt \& Stice (1994) which shows if the overall corporate financial condition is a major factor in determining the cost of audit services. Poor financial conditions are associated with higher litigation risk, more audit evidences needed, and higher audit service fees. The LIQUID variable shows a significant negative result on audit service fees. This indicates that audit service fee increases only in companies that have a greater risk and become auditor's consideration over the liquidation risk faced by their clients.

The variable BIG4 as a dummy variable for the type of KAP shows a significant positive result on the audit service fees. This is in accordance with the initial prediction that Big 4 KAP will charge a higher audit service fee than non Big 4 KAP. Big 4 is believed to provide better audit services than non Big 4 KAP. In addition, Big 4 has auditors who have industry specialties so that their abilities are not in doubt.

The C_AUDITOR variable as a dummy variable for auditor switching shows insignificant positive result on the audit service fees. This means that there is no low balling effect in the initial period of the audit engagement. The result of research conducted by Ebrahim (2010) in accordance with the result in this study, where the study result of Ebrahim (2010) indicates an increase in audit service fees as a result of the SOX Act in 2002. Auditors who have just audited a company still charge audit service fees in accordance with the expenses borne by the auditors. The need for auditors is currently getting bigger and auditors are trusted as one of the parties who can provide relevant information for the users of financial statements so that auditors continue to prioritize their independence. 
The LNGDP variable has a significant positive effect on audit service fees. This indicates that a country with a high level of gross domestic product per capita is subject to a higher audit service fee. This is due to GDP per capita shows the standard of living of a country and is one of the benchmarks to see the market value of goods and services so that the relationship between GDP and the cost of audit services is directly proportional.

\section{CONCLUSIONS}

This study aims to find empirical evidence of the effect of earnings management on audit service fees. The results of this study indicate that earnings management has a significant effect on audit service fees. This shows that earnings management carried out by company management increases audit risk so that the compensation received by the auditors is a greater audit service fees. Firm size measured by total assets and audit complexity measured by the amount of inventory and receivables on total assets have significant positive effect on the audit service fees. This indicates that if these two components are factors considered by the auditor when determining the amount of audit fees, because the larger and more complex a company is, the auditor will need a longer time to perform an audit. Audit risk is measured by the losses reported by the company, the rate of return on assets, the ratio of book value to market value, changes in revenue divided by total assets in the previous year and the company's ability to pay off short-term and long-term liabilities. The net loss reported by the company and the company's ability to pay off long-term liabilities have a significant positive effect on audit service fees. This is related to the sustainability of the company in the future. The level has a significant negative effect. These results indicate that increases in ROA, BTM, and LIQUID are normal things that occur in every company. Changes in revenue have a positive effect on audit service fees.

The type of auditor has a significant positive effect on audit service fees. This shows that Big 4 KAP charges higher audit service fees because it has already had good reputation and known service quality. Auditors switching has no significant positive effect on service fees. GDP per capita has a significant positive effect. This relates to the prices for services and goods set in that country.

This study has several limitations so that further research can use subsidiary proxies, both domestic and overseas subsidiaries, where the results of the previous studies show that the number of subsidiaries has a significant positive effect on audit service fees. This study has not considered the location of the company office, where the previous research shows that companies located in the city center pay higher fees for audit services. This study only examines the effect of earnings management from the previous year with audit service fees in this year. It is expected that further research will make a comparison between the effect of earnings management in the previous year and this year.

This study has implications for auditors that the presence of evidence regarding a significant positive effect between earnings management in the previous year and audit service fees indicates that earnings management is an inherent risk that the auditor must be aware of in the initial period of the audit engagement. Therefore, it is expected that the audit procedures carried out can detect this.

\section{REFERENCES}

Abbott, L. J., Parker, S., \& Peters, G. F. (2006). Earnings management, litigation risk, and asymmetric audit fee responses. Auditing: A journal of Practice \& theory, 25(1), 85-98.

Alali, F. (2011). Audit fees and discretionary accruals: Compensation structure effect. Managerial Auditing Journal. https://doi.org/10.1108/02686901111094994

Aljifri, K. (2007). Measurement and Motivations of Earnings Management : A Critical Perspective. Journal of Accounting-Business \& Management. 14.

Antle, R., Gordon, E., Narayanamoorthy, G., \& Zhou, L. (2006). The joint determination of audit fees, nonaudit fees, and abnormal accruals. Review of Quantitative Finance and Accounting. 27(3), 235-266. 
https://doi.org/10.1007/s11156-006-9430-y

Antle, R., \& Nalebuff, B. (1991). Conservatism and Auditor-Client Negotiations. Journal of Accounting Research. 29, 31-54. https://doi.org/10.2307/2491002

Bazrafshan, E., Kandelousi, A. S., \& Hooy, C. W. (2014). The impact of earnings management on the extent of disclosure and true financial performance: Evidence from listed firms in Hong Kong. British Accounting Review. 48(2), 206-219. https://doi.org/10.1016/j.bar.2015.09.001

Bedard, J.C., \& Johnstone, K. M. (2004). Earnings manipulation risk, corporate governance risk, and auditors' planning and pricing decisions. Accounting Review. https://doi.org/10.2308/accr.2004.79.2.277

Choi, J. H., Kim, J. B., \& Zang, Y. (2010). Do abnormally high audit fees impair audit quality? Auditing. 79(2), 277-304. https://doi.org/10.2308/aud.2010.29.2.115

Chung, H., \& Kallapur, S. (2003). Client Importance, Nonaudit Services, and Abnormal Accruals. Accounting Review. 78(4), 931-955. https://doi.org/10.2308/accr.2003.78.4.931

DeAngelo, L. E. (1981). Auditor independence, "low balling", and disclosure regulation. Journal of Accounting and Economics. https://doi.org/10.1016/0165-4101(81)90009-4

Ebrahim, A. (2010). Audit fee premium and auditor change: The effect of Sarbanes-Oxley Act. Managerial Auditing Journal. 3(2), 113-127. https://doi.org/10.1108/02686901011008936

Flannery, M. J., Kwan, S. H., \& Nimalendran, M. (2004). Market evidence on the opaqueness of banking firms' assets. Journal of Financial Economics. 71(3) https://doi.org/10.1016/S0304-405X(03)00185-5

Ghanbari, A., Askarian, H., \& Matinfar, M. (2014). The effect of real earnings management on audit fees in listed companies in Tehran Stock Exchange. Management Science Letters. 4(10), 2251-2260. https:// doi.org/10.5267/j.msl.2014.9.011

Godfrey, J., Hodgson, A., Tarca, A., Hamilton, J., \& Holmes, S. (2010). Accounting Theory (7th ed.) (7th ed.). Wiley \& Sons.

Gul, F. A., Chen, C. J. P., \& Tsui, J. S. L. (2003). Discretionary Accounting Accruals, Managers' Incentives, and Audit Fees. In Contemporary Accounting Research. https://doi.org/10.1506/686E-NF2J-73X6-G540

Hackenbrack, K., Jenkins, N. T., \& Pevzner, M. (2012). Relevant but Delayed Information in Negotiated Audit Fees: Evidence from Stock Price Crashes. SSRN Electronic Journal. 33(4), 95-117 https://doi. org/10.2139/ssrn. 1668983

Hay, D. C., Knechel, W. R., \& Wong, N. (2006). Audit fees: A meta-analysis of the effect of supply and demand attributes. In Contemporary Accounting Research. 23(1), 141-191. https://doi.org/10.1111/ j.1524-4733.2006.00093.x

Healy, P. M., \& Wahlen, J. M. (1999). A review of the earnings management literature and its implications for standard setting. In Accounting Horizons. https://doi.org/10.2308/acch.1999.13.4.365

IAI. (2017). Kerangka dasar penyusunan penyajian laporan keuangan. Standar Akuntansi Keuangan. https:// doi.org/10.1007/s13398-014-0173-7.2

Kothari, S. P., Leone, A. J., \& Wasley, C. E. (2005). Performance matched discretionary accrual measures. Journal of Accounting and Economics. https://doi.org/10.1016/j.jacceco.2004.11.002

Larcker, D. F., \& Richardson, S. A. (2004). Fees paid to audit firms, accrual choices, and corporate governance. In Journal of Accounting Research. https://doi.org/10.1111/j.1475-679X.2004.t01-1-00143.x

Madison, K. J. (2014). Agency Theory and Stewardship Theory Integrated, Expanded, and Bounded by Context : An Empirical Investigation of Structure, Behavior, and Performance within Family Firms. University of Tennessee,Knoxville. https://doi.org/10.17129/botsci.8

Nam, L. H. (2014). Earnings Management and Audit Fee Responses in New Zealand. SSRN Electronic Journal, 5233(ext 8340). https://doi.org/10.2139/ssrn.2388579

Omid, A. M., Khalili, P., \& Mohammadi, J. (2012). Type of Earnings Management and the Effects of Debt Contracts, Future Earnings Growth Forecast and Sales Growth: Evidence from Iran. International Research Journal of Finance \& Economics. 4(1), 7-16

Pratt, J., \& Stice, J. D. (1994). The Effects of Client Characteristics on Auditor Litigation Risk Judgments, Required Audit Evidence, and Recommended Audit Fees. The Accounting Review. 69(4), 639-656. https://doi.org/10.2307/248435

Raharjo, E. (2007). Teori Agensi dan Teori Stewrship dalam Perspektif Akuntansi. Fokus Ekonomi. 2(1), 37-46.

Reynolds, J. K., \& Francis, J. R. (2000). Does size matter? The influence of large clients on office-level auditor reporting decisions. Journal of Accounting and Economics. 30(3), 375-400. https://doi.org/10.1016/ S0165-4101(01)00010-6

Schelleman, C., \& Knechel, W. R. (2010). Short-term accruals and the pricing and production of audit 
services. Auditing: A Journal of Practice \& Theory, 29(1), 221-250.

Simunic, D. A. (1980). The Pricing of Audit Services: Theory and Evidence. Journal of Accounting Research. 18(1), 161-190 https://doi.org/10.2307/2490397

Wallace, W. A. (2004). The Economic Role of the Audit in Free and Regulated Markets. Research in Accounting Regulation.17(1), 267-298 https://doi.org/10.1016/S1052-0457(04)17012-4

Wallman, S. M. H. (1996). The future of accounting, part III: Reliability and auditor independence. Accounting Horizons. 10(1), 76-97. 